\title{
Comprehensive 1000 year climatic history from an intermediate-depth ice core from the south dome of Berkner Island, Antarctica: methods, dating and first results
}

\author{
Urs RUTH, ${ }^{1,2}$ Dietmar WAGENBACH, ${ }^{2}$ Robert MULVANEY, ${ }^{3}$ Hans OERTER, ${ }^{1}$ \\ Wolfgang GRAF, ${ }^{4}$ Henning PULZ, ${ }^{2}$ Genevieve LITTOT $^{3}$ \\ ${ }^{1}$ Alfred Wegener Institute for Polar and Marine Research, Columbusstrasse, D-27568 Bremerhaven, Germany \\ ${ }^{2}$ Institute of Environmental Physics, University of Heidelberg, Im Neuenheimer Feld 229, D-69120 Heidelberg, Germany \\ E-mail: urs.ruth@urz.uni-heidelberg.de \\ ${ }^{3}$ British Antarctic Survey, Natural Environment Research Council, Madingley Road, Cambridge CB3 OET, England \\ ${ }^{4}$ GSF-Forschungszentrum für Umwelt und Gesundheit, Postfach 1129, D-85758 Neuherberg, Germany
}

\begin{abstract}
A $181 \mathrm{~m}$ deep ice core drilled in 1994/95 on the south dome of Berkner Island, Antarctica, was analyzed for stable isotopes, major ions and microparticle concentrations. Samples for ion chromatography were prepared by using a novel technique of filling decontaminated sample from a device for continuous ice-core melting directly into the sample vials. The core was dated through identification of volcanic horizons and interpolative layer counting. The core, together with a similar core from the north dome, reveals a $\mathbf{1 0 0 0}$ year history of relatively stable climate. Temporal variations in the two cores deviate from each other owing to changing patterns of regional-scale circulation; the best correspondence between them is found for $\mathrm{MSA}^{-} . \delta^{18} \mathrm{O}$, accumulation rate and a sea-salt proxy show only negligible correlation, which suggests a complex meteorological setting. Increasing annual accumulation is observed for the last 100 years. A period of increased sea-salt concentrations started around $\mathrm{AD} 1405$, as has also been observed in other cores. Microparticle concentrations are on average 1220 particles $\left(\geq 1.0 \mu \mathrm{m}\right.$ diameter) $\mathrm{mL}^{-1}$; they are enhanced from AD 1200 to 1350 , possibly because of a higher atmospheric mineral dust load or because local volcanic activity was stronger than previously thought. Microparticles and $\mathrm{NH}_{4}{ }^{+}$show marked but multiple and very irregular sub-annual peaks; longterm stacking of 1 year data intervals yields seasonal maxima in austral spring or mid-summer, respectively. Post-depositional redistribution was observed for $\mathrm{MSA}, \mathrm{NO}_{3}{ }^{-}$and $\mathrm{F}^{-}$at volcanic horizons.
\end{abstract}

\section{INTRODUCTION}

Berkner Island holds a marine ice sheet which is independent of the Antarctic ice sheet at present (Fig. 1). Surrounded by the Ronne and Filchner Ice Shelves, it rises to a northern (720 ma.s.I.) and a southern dome (890 ma.s.l.) 50 and $200 \mathrm{~km}$ from the open sea in summer, respectively. Meteorological (Reijmer and others, 1999) and field observations show that the domes are not affected by the katabatic wind regime; and due to the dome topography they are expected to provide a good climatic record of the Weddell Sea region.

In 1989/90 two 11 m deep firn cores were recovered from the domes, which showed clear seasonal cycles and a marked concentration decrease of marine tracers with increasing distance from the coast (Wagenbach and others, 1994). Two cores of intermediate depth were drilled during the 1994/95 joint field seasons of the Alfred Wegener Institute (AWI), Germany, and the British Antarctic Survey. The cores reached depths of $151 \mathrm{~m}$ (R1, north dome) and $181 \mathrm{~m}$ (B25, $5 \mathrm{~km}$ from south dome) and span approximately 600 and 1200 years, respectively. Currently, a deep drilling at the south dome is underway as a European Programme for Ice Coring in Antarctica (EPICA) associated project; a core to bedrock is expected to include the ultimate deglaciation if Berkner Island was not overrun by the Antarctic ice sheet.

First results from the intermediate cores have been published, focusing on R1 (Mulvaney and others, 2002). Here we present a revised dating of the B25 core; chemical and isotopic time series for both cores are shown and discussed.

For the chemical analyses of the B25 core a set-up for continuous ice-core melting was used that also provided samples for subsequent standard ion chromatography (IC) measurements. This new development is also presented here.

\section{ICE-CORE ANALYSIS}

The B25 ice core was analyzed continuously using a combination of discrete sampling and continuous flow analysis (CFA) methods. Electrical conductivity measurements $(E C M)$ on the frozen ice core were performed in the field, and density was measured at high depth resolution in the cold laboratory at AWI in Bremerhaven (Gerland and others, 1999). Samples for $\delta^{18} \mathrm{O}$ and $\delta \mathrm{D}$ were cut in roughly annual resolution. Electrolytical conductivity $\sigma, \mathrm{Ca}^{2+}, \mathrm{NH}_{4}{ }^{+}$ and water-insoluble microparticle concentrations were measured in a CFA system at an effective depth resolution better than $1.0 \mathrm{~cm} . \mathrm{F}^{-}, \mathrm{MSA}^{-}, \mathrm{Cl}^{-}, \mathrm{NO}_{3}{ }^{-}$and $\mathrm{SO}_{4}{ }^{2-}$ concentrations were measured by IC at sample resolutions of 2.0$6.5 \mathrm{~cm}$; these samples were not cut and decontaminated individually, but prepared using the CFA system, a novel method of sample preparation that is now being applied widely within the EPICA project. While the ECM and stableisotope measurements are described elsewhere (Mulvaney and others, 2002), the chemical analyses are detailed below. 


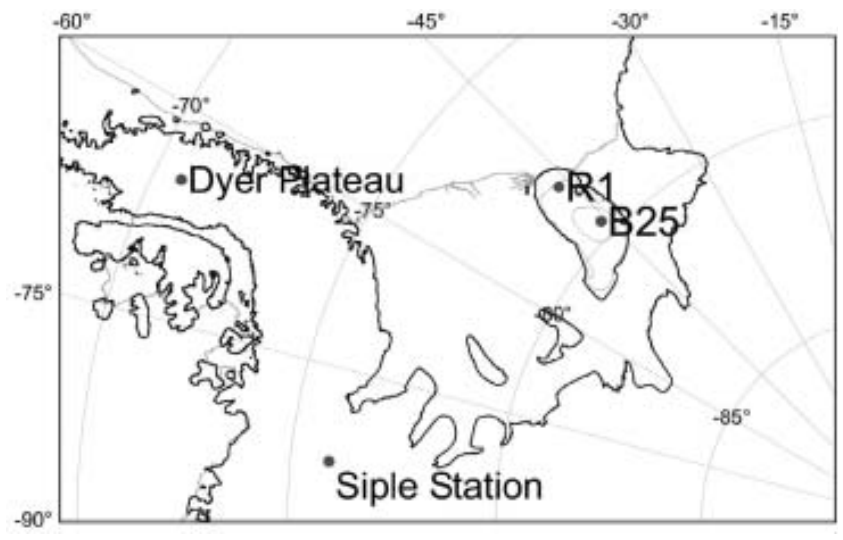

Fig. 1. Map of Berkner Island and the Filchner-Ronne Ice Shelf area. The drill sites of cores R1 (Reinwarthöhe, north dome) and B25 (Tyssenhöhe, south dome) are indicated. Also shown are two sites on the Antarctic Peninsula discussed in the text.

Stable-isotope and ECM measurements were performed on the whole core; the chemical analyses were performed from the top to $\approx 150 \mathrm{~m}$ depth.

\section{The melting device}

An apparatus for continuous ice-core melting has been developed at the Institute of Environmental Physics (IUP), Heidelberg, Germany, for operation in a warm laboratory. It consists of a freezing unit to prevent uncontrolled melting of the ice core, and a melt head $(\mathrm{MH})$ which is mounted at the bottom of the unit, for controlled ice-core melting (see Fig. 2). The cylinder-shaped freezer hosts a concentric tube of Plexiglas to guide the core to the $\mathrm{MH}$. The $\mathrm{MH}$ has two concentric sections that are drained separately, and only the sample from the inner, clean part of the ice core is used for the analyses, while the sample from the outer, possibly contaminated part is discarded. The $\mathrm{MH}$ is specially designed for processing porous firn cores. It is made from anodized aluminium and has narrow slits for this purpose (see Röthlisberger and others, 2000b; Sommer and others, $2000 \mathrm{a}, \mathrm{b})$. The whole unit is rotatable into horizontal position to load it with a new ice core or for service. Each melt run started with a $5 \mathrm{~cm}$ long strip of artificial Milli-Q ice to ensure stable melting conditions once the real sample reached the $\mathrm{MH}$. The freezer may be evacuated and purged with $\mathrm{N}_{2}$ gas to reduce gaseous contaminations when melting firn. Typical melt-parameter values included a freezer temperature of $-20^{\circ} \mathrm{C}$ and a $\mathrm{MH}$ temperature of $+20^{\circ} \mathrm{C}$; this resulted in typical melt speeds of $2.6 \mathrm{~cm} \mathrm{~min}^{-1}$ for ice and $3.9 \mathrm{~cm} \mathrm{m^{-1 }}$ for firn. The meltwater runs first through a debubbler and is then pumped by peristaltic pumps into individual flowlines for analyses.

The samples for discrete IC measurements were taken from the flowline of the electrolytical conductivity and particle measurements, neither of which contaminate the sample. The liquid was filled directly into pre-cleaned Dionex polyvials $(5 \mathrm{~mL})$ which could be transferred directly into a Dionex autosampler for subsequent IC measurements. To switch from one vial to the next, a modified Dionex autosampler was used controlled by an external computer. In order not to lose sample during vial exchange $(\approx 25 \mathrm{~s})$ a buffer reservoir was employed. With such a set-up, a depth resolution of better than $1.0 \mathrm{~cm}$ is possible for the IC samples depending on the $\mathrm{MH}$ dimensions, the number of
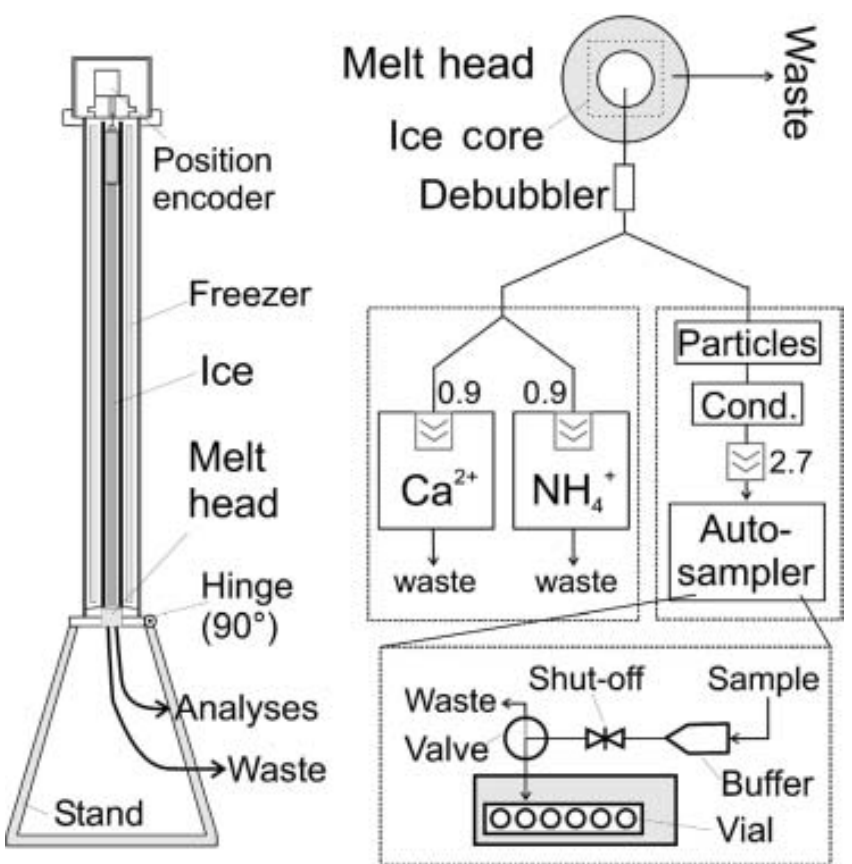

Fig. 2. Schematic illustration of the measuring set-up including the melting apparatus (left) and the analytical flow system (right); the automatic sampler is enlarged. Numbers indicate typical flow rates in $\mathrm{mL} \mathrm{min}^{-1}$.

'destructive' CFA lines used and the amount of liquid needed for each sample. In the current applications within the EPICA project, Coulter Counter accuvettes are used in custom-built autosamplers.

Samples for IC were not measured right away because of organizational constraints. They were refrozen directly after preparation and kept frozen until measurement. The whole procedure was checked against contamination. Taking ultraclean Milli-Q water as sample, contamination was monitored at three stages of the processing: the IC measurement alone ('IC blank'), the IC measurement including one freeze-thaw cycle ('freeze blank'), and the whole preparation process including cutting and melting via the $\mathrm{MH}$ ('process blank'). It was found that the extra freeze-thaw cycle for storage is not a source of contamination (see Table 1); however, sample preparation through melting leads to significant contamination in $\mathrm{SO}_{4}{ }^{2-}$, exceeding $10 \mathrm{ng} \mathrm{g}^{-1}$.

The $\mathrm{MH}$ was found to be the source, but the contamination was not eliminated. It may stem from particulates that are stuck in the interior construction of the $\mathrm{MH}$ and could not be washed out even under ultrasonic exposure. Another possibility is that the anodized aluminium of the $\mathrm{MH}$ itself is responsible, as the anodizing takes place in concentrated sulphuric acid; this seems unlikely, though, since the contamination was zero at the beginning and was detected only after some usage. The contamination does not pose a severe problem in this application because non-sea-salt (nss) $\mathrm{SO}_{4}{ }^{2-}$ concentrations are normally of the order of $100 \mathrm{ng} \mathrm{g}^{-1}$ in Berkner Island samples, i.e. well above the level of contamination.

\section{Detection systems and data analysis}

The electrolytical conductivity measurement was done using an electronic detector by Dionex or WTW together with a Dionex or a self-built cell, respectively. Water-insoluble microparticles were measured with a laser counter 
Table 1. Blank concentrations of the IC samples in three different categories as described in the text. All values in $\mathrm{ng} \mathrm{g}^{-1}$

\begin{tabular}{llllll}
\hline & $\mathrm{F}^{-}$ & $\mathrm{MSA}^{-}$ & $\mathrm{Cl}^{-}$ & $\mathrm{NO}_{3}{ }^{-}$ & $\mathrm{SO}_{4}{ }^{2-}$ \\
& & & & & \\
\hline $\begin{array}{l}\text { IC blank } \\
\text { Freeze }\end{array}$ & $0.4 \pm 0.3$ & $0.2 \pm 0.6$ & $1.7 \pm 1.6$ & $0.9 \pm 0.9$ & $0.9 \pm 1.2$ \\
$\begin{array}{l}\text { blank } \\
\text { Process }\end{array}$ & $0.9 \pm 0.2$ & $0.3 \pm 0.4$ & $1.3 \pm 0.6$ & $1.0 \pm 0.5$ & $1.2 \pm 0.8$ \\
& & $0.3 \pm 0.6$ & $2.0 \pm 1.0$ & $1.0 \pm 0.9$ & $13.4 \pm 3.8$
\end{tabular}

developed by Klotz Company in collaboration with the IUP (see Ruth and others, 2002, 2003). The CFA systems for $\mathrm{Ca}^{2+}$ and $\mathrm{NH}_{4}{ }^{+}$were provided by the University of Bern, Switzerland. The IC measurements used a Dionex DX 500 with an AS12 anion separator column.

Data analysis included in a first step the conversion of recorded detector outputs to calibrated concentrations. The time lags from sample melting until detection are different for each system and needed to be corrected individually to avert systematic errors in seasonal phasings.

The non-sea-salt contribution to conductivity $\sigma_{\text {nss }}$ was calculated from the measured electrolytical conductivity $\sigma$ by subtracting the sea-salt contribution as calculated from the $\mathrm{Ca}^{2+}$ concentrations: $\sigma_{\mathrm{nss}}=\sigma-k\left[\mathrm{Ca}^{2+}\right] ; k$ was derived experimentally, and $k=0.176 \mu \mathrm{S} \mathrm{cm}^{-1}\left(\mathrm{ng} \mathrm{g}^{-1}\right)^{-1}$ was used. The calculation of $\mathrm{nssSO}_{4}{ }^{2-}$ concentrations was based on $\left[\mathrm{Cl}^{-}\right]$; it needs to account for aerosol fractionation, and the ion ratio from sea water does not apply; following the investigations by Minikin and other (1994), $\left[\mathrm{SO}_{4, \mathrm{nss}}{ }^{2-}\right]=$ $\left[\mathrm{SO}_{4}{ }^{2-}\right]-0.0315\left[\mathrm{Cl}^{-}\right]$was used.

\section{DATING}

Owing to the accumulation rate of $130 \mathrm{~kg} \mathrm{~m}^{-2} \mathrm{a}^{-1}$ (see below) and the high-resolution measurements, seasonal cycles could be identified for several components throughout most of the core. Thus, dating was achieved by multiparameter counting of annual layers. However, the seasonal variations were ambiguous at times, as all components measured at sub-seasonal depth resolution may show multiple annual peaks. Therefore, to achieve a core chronology with long-term reliability it was necessary to constrain the dating by selected volcanic horizons.

\section{Counting of seasonal cycles}

As is explained below, the austral winter layer was marked for each year. Figures 3 and 4 give examples of seasonal variations with distinctness above and below average, respectively. Seasonal variations were most obvious in ECM and $\mathrm{Ca}^{2+}$ signals. The ECM signal represents mainly the concentration of free $\mathrm{H}^{+}$, which is higher in austral summer than in winter. This seasonal variation is amplified by events of high sea-salt input, which occur mainly during winter and cause a drop in the ECM signal to zero, thus forming a good indicator for austral mid-winter layers. However, occasional strong inputs of mineral dust aerosol, which may occur mostly during the summer months, or an unusual summer-time sea-salt event can also cause a reduction of the ECM to zero. Therefore, the ECM signal is

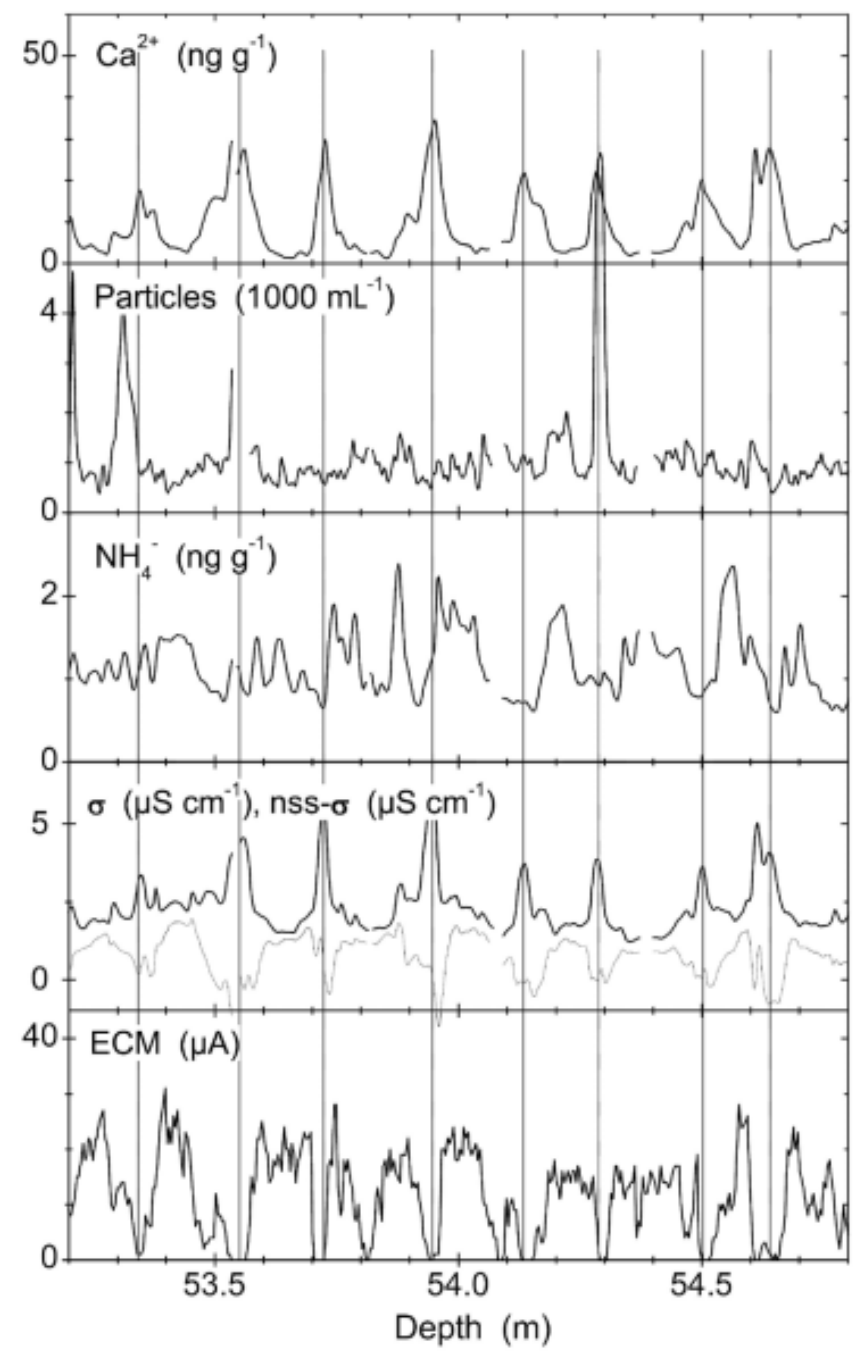

Fig. 3. Example of annual layers (distinctness better than average). Vertical lines mark austral mid-winter (July) layers as from the annual-layer counting.

not strictly seasonal, and layer counting based on ECM alone will be somewhat unreliable.

At Berkner Island, $\mathrm{Ca}^{2+}$ is derived predominantly from sea-salt aerosol and to a lesser extent from mineral dust. At coastal Antarctic sites the sea-salt aerosol is deposited mainly during mid-winter (e.g. Wagenbach and others, 1994, 1998); this was commonly believed to be due to the greater storm activity during that season, but now the seasonally greater extent of sea ice, which serves as an effective source for sea-salt aerosols through frozen brine and frost flowers, is shown to be the driving mechanism (Wagenbach and others, 1998; Rankin and others, 2000). Usually, there are several $\mathrm{Ca}^{2+}$ peaks every year, but normally there is a dominant one. Therefore, large $\mathrm{Ca}^{2+}$ peaks were taken as markers for mid-winter horizons.

Berkner Island has no areas of exposed rock, and mineral dust particles must have been transported long distances. It is currently being investigated whether the dominant dust sources for Berkner Island are Patagonian or other South American deserts, as is believed for East Antarctica based on isotopical and mineralogical studies (Basile and others, 1997), or whether other sources are also important. At Berkner Island, dust concentrations usually peak several times a year and do not show a clear seasonality (see Figs 3 and 4). This is similar to the observation by Thompson and 
others (1994) for ice cores from Dyer Plateau and Siple Station, both on the Antarctic Peninsula, and is contrary to results from a few aerosol measurements and high-resolution firn studies at Neumayer station (Wagenbach, 1996) and South Pole (Mosley-Thompson, 1980; Tuncel and others, 1989), which indicate maximal crustal concentrations during mid-summer. At Berkner, dust peaks usually occur independently of sea-salt peaks, but sometimes they are concurrent. The high-resolution dust profiles played only a secondary role in the counting of annual layers; the presence of a strong dust peak prohibited the assignment of a winter layer based on an ECM minimum alone, and it raised questions about the assignment of a winter layer based on a sea-salt peak.

$\mathrm{NH}_{4}{ }^{+}$also showed marked variations, but they appeared to be mostly sub-seasonal (see Figs 3 and 4 ). In contrast to $\mathrm{Ca}^{2+}$, there was not normally one dominant peak every year. $\mathrm{NH}_{4}{ }^{+}$ peaks are sometimes associated with dust or with sea-salt events, but they may also occur fully independently. $\mathrm{NH}_{4}{ }^{+}$ seems to be derived from multiple sources (continental and possibly marine) or seems to follow multiple transport pathways. The $\mathrm{NH}_{4}{ }^{+}$variations were irregular in strength and timing and therefore were not used as primary indicators for annual layers. But as the source strength for $\mathrm{NH}_{4}{ }^{+}$may be expected to be seasonal and highest in summer (Legrand and others, 1998), we used peaks of $\mathrm{NH}_{4}{ }^{+}$as soft contraindicators for winter layers in the counting procedure.

Another useful parameter for counting annual layers was the non-sea-salt conductivity $\sigma_{\text {nss }}$. While $\sigma$ peaks in midwinter due to the high sea-salt concentrations, $\sigma_{\text {nss }}$ is found to peak in mid-summer (see Figs 3 and 4), which suggests acidic aerosols (mainly biogenic $\mathrm{SO}_{4}{ }^{2-}$ and $\mathrm{HNO}_{3}$ ). However, no priority was given to $\sigma_{\text {nss }}$ since it is a derived measure, and small errors in the peak phasings or shapes of $\left[\mathrm{Ca}^{2+}\right]$ and $\sigma$ can lead to large artefacts in $\sigma_{\text {nss }}$

It proved most practical to mark the mid-winter horizons in the core for each year, as the sea-salt events were the most regularly observed and most prominent events in the record. These horizons were taken as July of the respective year. Accordingly, the annual averages presented below were taken from July of the assigned to July of the previous year.

\section{Volcanic markers}

The layer counting was constrained by unambiguously identified volcanic horizons. Unfortunately, these horizons are few because volcanogenic $\mathrm{SO}_{4}{ }^{2-}$ often cannot be clearly identified. This is mainly due to the large quantities of seasalt-derived $\mathrm{SO}_{4}{ }^{2-}$ and marine-biogenic $\mathrm{SO}_{4}{ }^{2-}$ which obscure the volcanogenic contribution; also, because of possibly volcanogenic $\mathrm{Cl}^{-}$contributions, the use of $\mathrm{Cl}^{-}$as a sea-salt indicator may weaken volcanic $\mathrm{SO}_{4}{ }^{2-}$ peaks.

Figure 4 shows the volcanic horizons of Tambora, Indonesia (eruption AD 1815), and Figure 5 the '1259unknown' sequence. These are the two volcanic events identified most clearly in the B25 core. Such identifications are based on (i) enhancement of ECM and/or ECM winter minimum not going completely to zero, (ii) enhancement of $\mathrm{nsSSO}_{4}{ }^{2-}$, (iii) $\mathrm{NO}_{3}{ }^{-}$and MSA migrated outward (see below), and (iv) possibly $\mathrm{F}$ enhancement. $\mathrm{A}$ list of all identified volcanic events is given in Table 2.

It should be noted that the $\mathrm{nsSO}_{4}{ }^{2-}$ peak of the Huaynaputina (Peru) horizon (AD 1600), which was rather minor, was not used alone to identify the volcano. Instead, the horizon was recognized based on a combination of a

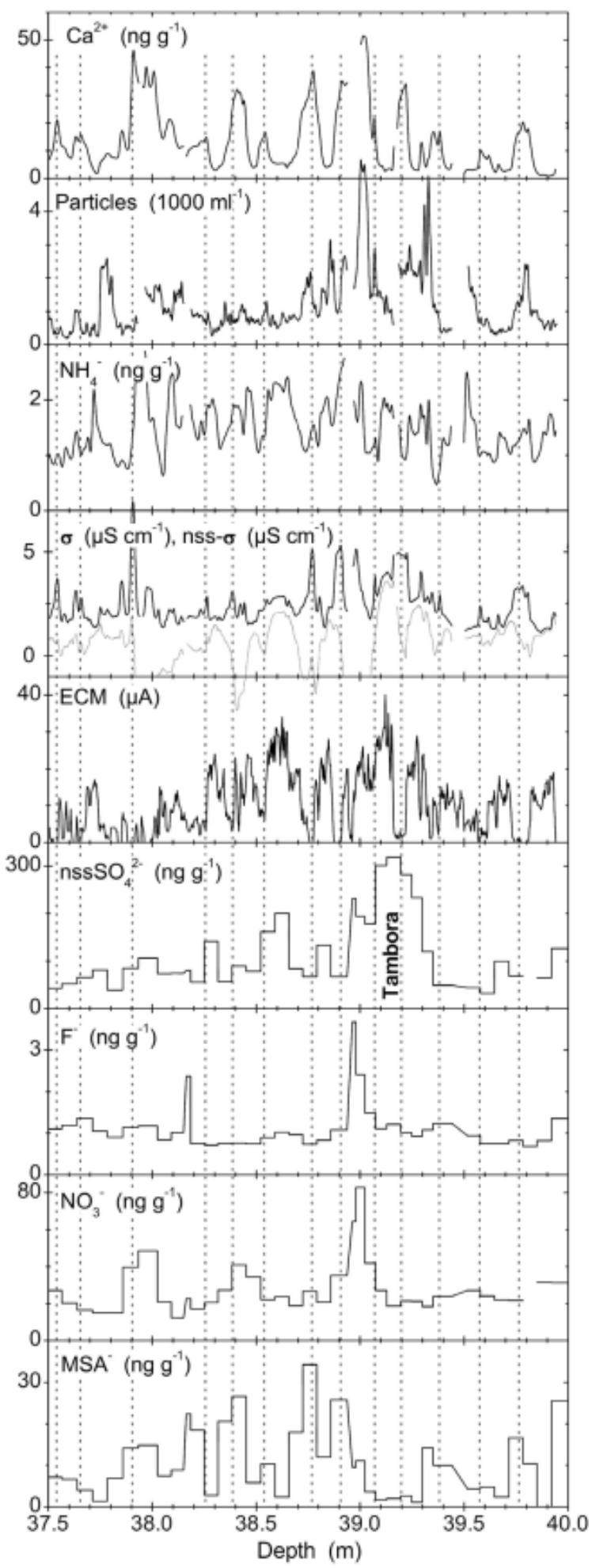

Fig. 4. Example of annual layers (upper panels; distinctness below average) and the Tambora volcanic horizon used for dating (lower panels). Vertical lines mark austral mid-winter layers. $\mathrm{F}^{-}, \mathrm{NO}_{3}{ }^{-}$and $\mathrm{MSA}^{-}$exhibit post-depositional redistribution around the Tambora layer.

$\mathrm{nsSSO}_{4}{ }^{2-}$ peak and a preceding particle peak, which is very distinct. Such a signature is reported by Thompson and others (1994) for the Dyer Plateau and Siple Station ice cores and dated from AD 1598 to 1600.

\section{Results and accuracy}

The resulting depth-age relationship, shown in Figure 6a along with the volcanic fix-points used to guide the layer 


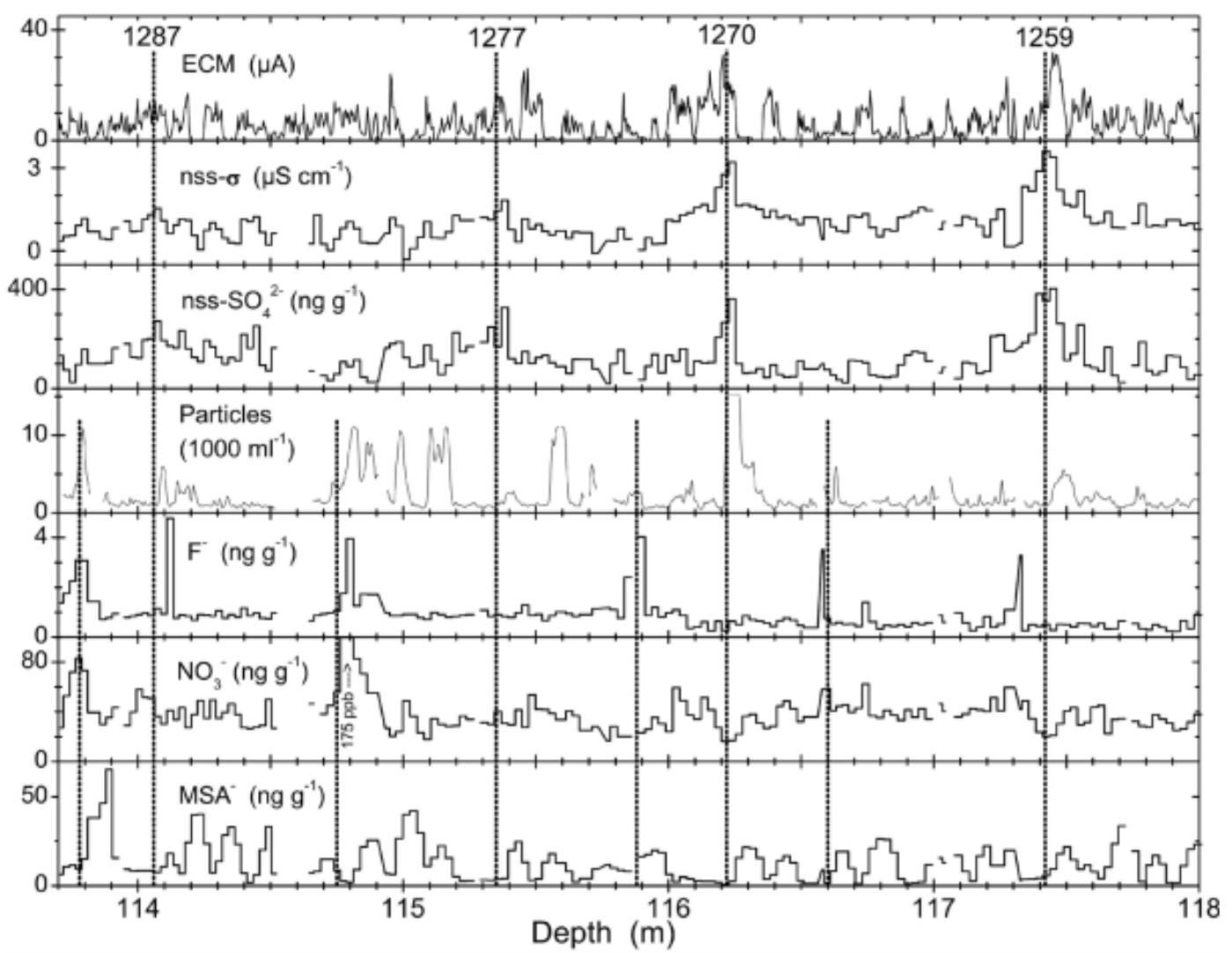

Fig. 5. The volcanic sequence of 1259-unknown and thereafter. Vertical lines (full length) indicate the well-known quadruple of events (e.g. Langway and others, 1995); numbers denote years (AD) according to the B25 chronology derived here. Half-length vertical lines indicate possible additional volcanic events previously unrecognized.

counting, is a rather smooth curve. Also shown is the 1954 Tritium Horizon (Huke, 1998) from the neighboring B24 core ( $1 \mathrm{~m}$ apart) which was used to confirm the dating. The preliminary dating by Mulvaney and others (2002) is revised by up to 15 years in the part above and by up to 40 years in the part below the 1259 volcanic horizon.

A simple ice-flow model was applied to fit the surface and the 1259 horizon (Nye, 1963). For a proposed ice-sheet

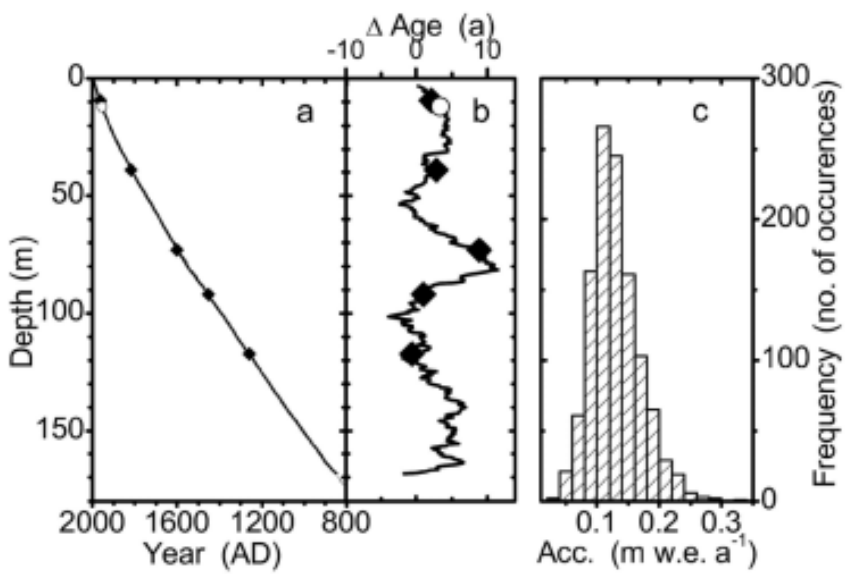

Fig. 6. (a) The core chronology obtained for the B25 ice core by annual-layer counting (solid line). Solid symbols mark the volcanic horizons used to constrain the layer counting; the open symbol marks the 1954 tritium horizon (Huke, 1998). The Nye model (see text) is indistinguishable from the solid line shown. (b) Age difference between the core chronology and the Nye model. (c) Frequency distribution of the annual net accumulation as derived from the core chronology (strain-corrected). thickness of $850 \mathrm{mw}$.e., which corresponds to approximately $950 \mathrm{~m}$ of true ice thickness, parameter optimization yields an average accumulation rate of $A=130 \mathrm{~kg} \mathrm{~m}^{-2} \mathrm{a}^{-1}$. The deviation of the counted core chronology from the Nye model is always $<12$ years and typically around 5 years (see Fig. 6b). The good agreement shows that, as a first-order approximation, the accumulation rate was fairly constant over the time covered, and that the simple ice-flow model may be applied to the $181 \mathrm{~m}$ long B25 core to obtain a firstorder chronology.

The flow model was used to calculate a strain correction for each annual-layer thickness as derived from the counting. This yields the net accumulation for each year. The frequency distribution of the annual net accumulations is shown in Figure $6 \mathrm{c}$ in a histogram plot. It exhibits approximately log-normal behaviour, with a maximum around $130 \mathrm{~kg} \mathrm{~m}^{-2} \mathrm{a}^{-1}$ and no sharp cut-off at either side.

The accuracy of the dating in between two volcanic fixpoints was estimated experimentally by repeated counting of the same interval by six different persons. This yielded that for any point $\mathrm{P}$ which is $n$ years apart from the nearest fixpoint, the dating accuracy is better than $\approx 0.8 \cdot \sqrt{n}$. The same accuracy is inferred from the dating error when originally the layer counting had not been forced through the volcanic horizons. Based on this estimate, the dating should be better than $\approx 8$ years throughout the record presented here.

\section{RESULTS}

Average values of characteristic measures are given in Table 3 for both cores. Sea-salt components show a clear 
Table 2. List of all identified volcanic events in the B25 core

\begin{tabular}{llll}
\hline & $\begin{array}{l}\text { Year of } \\
\text { deposition }\end{array}$ & $\begin{array}{l}\text { Suggested } \\
\text { depth } \\
\mathrm{m}\end{array}$ & $\begin{array}{l}\text { Used for } \\
\text { dating }\end{array}$ \\
& & & \\
\hline Agung, Indonesia & 1964 & 9.47 & $\mathrm{Y}$ \\
Krakatau, Indonesia & 1884 & 26.19 & $\mathrm{~N}(1888)$ \\
Tambora, Indonesia & 1816 & 39.10 & $\mathrm{Y}$ \\
Huaynputina, Peru & 1600 & 73.00 & $\mathrm{Y}$ \\
Kuwae, Vanuatu & 1454 & 91.90 & $\mathrm{Y}$ \\
1286 unidentified & $\sim 1286$ & 114.05 & $\mathrm{~N}(1287)$ \\
1278 unidentified & $\sim 1278$ & 115.35 & $\mathrm{~N}(1277)$ \\
1270 unidentified & $\sim 1270$ & 116.20 & $\mathrm{~N}(1270)$ \\
1259 unidentified & 1259 & 117.40 & $\mathrm{Y}$ \\
1229 unidentified & $\sim 1229$ & 120.95 & $\mathrm{~N}(1232)$ \\
& & & \\
\hline
\end{tabular}

Notes: Dates of deposition are from Moore and others (1991) and Langway and others (1995). If the event was not used to force the annual-layer counting, the date of the event is given for the B25 core.

decrease from north dome to south dome, as expected. It is noteworthy that $\mathrm{nsSO}_{4}{ }^{2-}$ concentrations are higher at south dome, while MSA concentrations are slightly lower. This is contrary to Wagenbach and others (1994) who found $\mathrm{nssSO}_{4}{ }^{2-}$ lower at south dome by $25 \%$; however, Minikin and others (1994) found very little dependence on the distance from the coast for $\mathrm{nsSO}_{4}{ }^{2-}$ concentrations in the Filchner-Ronne Ice Shelf area.

\section{Time series}

The time series of selected components are presented in Figure 7. In general they show a 1000 year record of relatively stable climate and environmental conditions. Only small trends are observed for all measured components over the past 1000 years; the variability of the smoothed datasets is only moderate and takes place mainly on multi-decadal to centennial time-scales, while the variability of the annual averages may be substantial. Smoothing was done by 500 iterations binomial filtering of three points, which corresponds to a Gaussian average with full width at a 1/e maximum of 63 years or $\sigma=31.6$ years. Figure 7 also shows data of the core R1 from the Berkner Island north dome. There is a large amount of variability between the two cores and only limited covariation. In the following, selected components will be discussed individually.

The temperature proxy $\delta^{18} \mathrm{O}$ shows no first-order trends over the whole record, and a peak-to-peak amplitude of the multi-decadal variations in the order of $1 \%$. The most prominent feature is a pronounced cooling during most of the 19th century by more than $1 \%$ in the smoothed data of B25. The record also shows an isotopically warm period from approximately AD 1230 to 1450, but no features may obviously be associated with the Little Ice Age (LIA) or the Medieval Warm Period (MWP) as they are known from some European or Greenlandic records (e.g. Fischer and others, 1998). Also, the period of the Maunder Minimum of sunspot numbers (AD 1645-1715) is not unusual in the record. There is a recent warming trend, but it does not exceed by magnitude or rate earlier changes in the record. The records from Berkner north and south domes do not show a clear covariance on multi-decadal or centennial time-scales; this may reflect varying circulation patterns effective for the area.

In both cores, the annual net accumulation shows a clear
Table 3. Characterization of the two drill sites and average values over the full core; for B25, averages are also given for the period covered by R1

\begin{tabular}{|c|c|c|c|}
\hline & \multicolumn{2}{|c|}{ South dome B25 } & \multirow{2}{*}{$\begin{array}{l}\text { North dome R1 } \\
\text { AD 1419-1994 }\end{array}$} \\
\hline & AD 1080-1994 & AD 1419-1994 & \\
\hline $\begin{array}{l}\text { Distance to } \\
\text { coast }(\mathrm{km})\end{array}$ & $\approx 200$ & $\approx 200$ & $\approx 50$ \\
\hline $\begin{array}{l}10 \mathrm{~m} \text { firn } \\
\text { temp. }\left({ }^{\circ} \mathrm{C}\right)\end{array}$ & -26.1 & -26.1 & -24.1 \\
\hline $\begin{array}{l}\text { Acc. rate } \\
\left(\mathrm{kg} \mathrm{m}^{-2} \mathrm{a}^{-1}\right)\end{array}$ & $130 \pm 40$ & $130 \pm 37$ & $207 \pm 92$ \\
\hline$\delta^{18} \mathrm{O}(\%)$ & $-28.3 \pm 1.7$ & $-28.4 \pm 1.7$ & $-25.5 \pm 1.6$ \\
\hline D excess & $5.09 \pm 2.1$ & $5.20 \pm 2.2$ & $6.00 \pm 2.6$ \\
\hline $\mathrm{Cl}^{-}\left(\mathrm{ng} \mathrm{g}^{-1}\right)$ & $441 \pm 203$ & $461 \pm 207$ & $854 \pm 463$ \\
\hline $\mathrm{nsSSO}_{4}^{2-}\left(\mathrm{ng} \mathrm{g}^{-1}\right)$ & $74.1 \pm 25.9^{(+)}$ & $74.8 \pm 27.5$ & $69.3 \pm 44.4$ \\
\hline $\mathrm{MSA}^{-}\left(\mathrm{ng} \mathrm{g}^{-1}\right)$ & $14.1 \pm 8.1^{(*)}$ & $14.6 \pm 8.8^{(*)}$ & $17.5 \pm 8.9$ \\
\hline $\mathrm{NO}_{3}^{-}\left(\mathrm{ngg}^{-1}\right)$ & $34.9 \pm 9.2^{(*)}$ & $34.2 \pm 7.1^{(*)}$ & $44.0 \pm 19.9$ \\
\hline $\begin{array}{l}\text { Microparticles } \\
\left(\mathrm{mL}^{-1}\right)\end{array}$ & $1220 \pm 1110^{(\mathrm{x})}$ & $1059 \pm 730^{(\mathrm{x})}$ & - \\
\hline
\end{tabular}

Notes: Uncertainties denote the $(1 \sigma)$ variability of annual means. Microparticle concentrations are for particles $\geq 1.0 \mu \mathrm{m}$ in diameter. ${ }^{(+)}$Values AD 1200-1350 excluded for B25. ${ }^{(*)}$ Values above $70 \mathrm{~m}$ depth excluded for B25. ${ }^{(\times)}$Values above $40 \mathrm{~m}$ excluded for B25.

enhancement during the period AD 1800-50. There is also an increase during the 20th century, as also seen throughout the Antarctic Peninsula and at South Pole (Thompson and others, 1994; Mosley-Thompson and others, 1995). No clear relationship is seen between $\delta^{18} \mathrm{O}$ and the annual accumulation, underlining the complicated meteorological situation of the Weddell Sea and Antarctic Peninsula region. Apart from the two covariant periods mentioned, the accumulation rates of the two cores exhibit a contra-variant behaviour. This could result from storms hitting either the north or the south dome more frequently. A remarkable feature is exhibited from $A D 1475$ to 1500: this period is characterized by a dramatic decrease in accumulation and a substantial cooling; there are low $\mathrm{Cl}^{-}$concentrations throughout the period until it terminates with one of the highest $\mathrm{Cl}^{-}$values in the record.

The sea-salt-derived component $\mathrm{Cl}^{-}$varies slightly and does not seem to depend on $\delta^{18} \mathrm{O}$ in either core. The two $\mathrm{Cl}^{-}$ records are not closely related to each other, which again may be the result of variable regional circulation patterns. There are two periods of elevated sea-salt concentrations in B25: AD 1400-1570 and AD 1830-1900. These could be caused by increased storminess during that time or by increased or prolonged sea-ice extent. $\delta^{18} \mathrm{O}$ does not indicate a cooling during either of the periods; however, the relationship between $\delta^{18} \mathrm{O}$ at Berkner and sea-ice extent in the Weddell Sea is unknown. Kreutz and others (1997) observe a marked increase of sea-salt tracers in Siple Dome, Antarctica, at $\mathrm{AD} 1389 \pm 12$, which they attribute to a postulated global event of enhanced atmospheric circulation connected with the LIA. The beginning of the corresponding increase may be recognized at AD $1405 \pm 6$ in the B25 core. Although this might suggest increased atmospheric circulation at a few selected Antarctic sites, this is not seen throughout Antarctica. Sommer and others (2000b) report no change of sea-salt-derived $\mathrm{Na}^{+}$concentrations at Dronning 


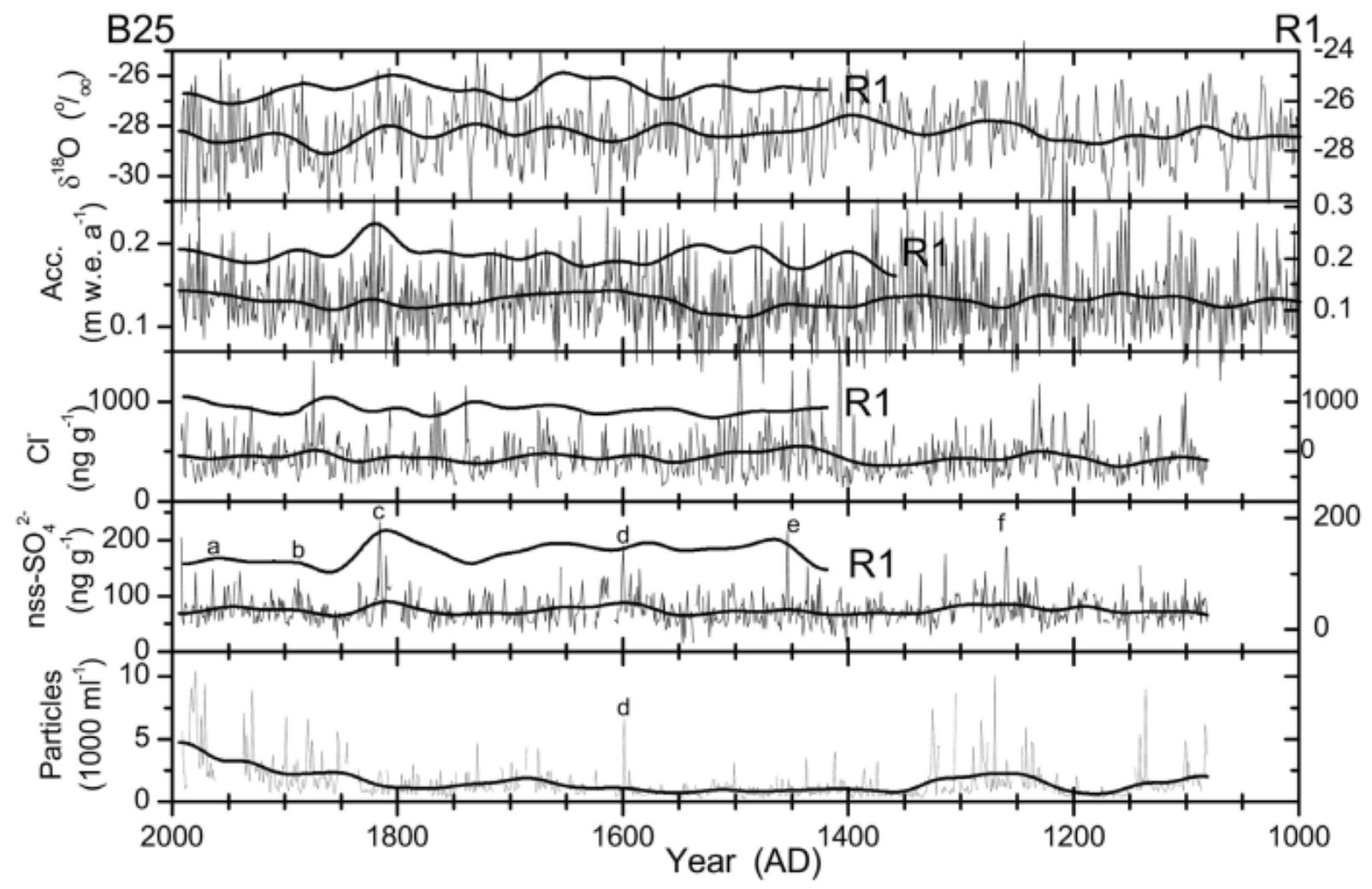

Fig. 7. Time series of the B25 core (solid lines, left scale) and of the R1 core (dotted lines, right scale). Fine lines are annual averages (B25 only); heavy lines are smoothed using a 500 iterations binomial filter (see text). Note different scales for the two cores in each panel: scales are set for both cores such that axes ranges divided by the respective data means are the same for both cores, i.e. relative variations are directly comparable by eye. Letters mark selected identified volcanic events: a. Agung; b. Krakatoa (uncertain); c. Tambora; d. Huaynaputina; e. Kuwae; f. 1259. The $\mathrm{SO}_{4}{ }^{2-}$ measurements suffered from system malfunction for AD 1200-1300, and calibrations may be uncertain there. Microparticle concentrations are for particles $>1.0 \mu \mathrm{m}$ in diameter.

Maud Land for the time around AD 1400. There is no coverage from R1 for that time.

$\mathrm{NsSSO}_{4}{ }^{2-}$ is dominated by marine biogenic contributions. Both cores show an enhancement in the time period AD 1750-1850. The variability is more pronounced in the $\mathrm{R} 1$ core, reflecting its proximity to the open ocean. A higher variability in $\mathrm{R} 1$ is also observed for $\mathrm{MSA}^{-}$(see Fig. 8). The variations in $\mathrm{MSA}^{-}$are in phase in both cores, although the $\mathrm{MSA}^{-}$record is disturbed in B25 (see below). Overall, MSA ${ }^{-}$ is the component that shows the best correspondence in both cores.

The microparticle record shows some prominent peaks even in the annually averaged data. Contamination was ruled out for each peak individually, and the peaks seem real at least in the part older than AD 1800. Most of the outstanding peaks are suspected to be of local volcanic origin; mineralogical studies should be performed to check this hypothesis. The prolonged enhancement of particle concentrations from $\mathrm{AD} 1200$ to 1350 may be due only in part to the volcanic activity during that time and may also be due to increased mineral dust source strength or transport efficiency. The large increase in particle concentrations in the more recent part of the record, however, may be due to contamination of the firn during drilling and handling of the core. Thompson and others (1994) also observed a strong, recent increase of particle concentrations on the Dyer Plateau, but their measurements may suffer from the same problems (Thompson and others, 1994). The enhanced particle concentrations from AD 1650 to 1710, i.e. during the Maunder Minimum of sun-spot numbers, may be significant; however, nothing equivalent is observed during the Spörer Minimum (AD 14201500) or the Wolf Minimum (AD 1290-1340).

To investigate the mutual dependence of temperature $\left(\delta^{18} \mathrm{O}\right)$, accumulation, and sea-salt $\left(\mathrm{Cl}^{-}\right)$concentrations, correlation coefficients were calculated and a principal component analysis (PCA) was carried out for B25. The correlation coefficients are all negligible $\left(\delta^{18} \mathrm{O}-\right.$ acc. $=0.07$; $\mathrm{O}-\mathrm{Cl}^{-}=-0.16$; acc $\left.-\mathrm{Cl}^{-}=-0.11\right)$, i.e. very little interdependence of the data. Similarly, the PCA finds three principal components with an explained total variance of $41 \%, 31 \%$ and $28 \%$, i.e. there is almost no redundancy in the data. This indicates a complex meteorological situation and suggests very variable storm-track patterns in the area.

\section{Post-depositional changes}

Post-depositional redistribution is observed for $\mathrm{MSA}^{-}, \mathrm{NO}_{3}{ }^{-}$ and $\mathrm{F}^{-}$at volcanic horizons. In Figures 4 and 5 it can clearly be seen that layers with high $\mathrm{nssSO}_{4}{ }^{2-}$ concentrations contain no significant amounts of $\mathrm{MSA}^{-}, \mathrm{NO}_{3}{ }^{-}$and $\mathrm{F}^{-}$. For $\mathrm{MSA}^{-}$a seasonal redistribution has already been observed in other cores (Wagenbach and others, 1994), and laboratory experiments have been performed to investigate the process (Pasteur and Mulvaney, 2000); Weller and others (2004) observe a net loss of $\mathrm{MSA}^{-}$in snow pits and shallow cores from Dronning Maud Land, which they explain by transport of MSA in the vapour phase. In B25, we see that $\mathrm{MSA}^{-}$tends to migrate away from the acidic layer and accumulate above 
the volcanic horizon. Presumably, the mechanism for the displacement is vapour-phase diffusion in the firn air. The large amount of $\mathrm{H}^{+}$from the volcanic $\mathrm{H}_{2} \mathrm{SO}_{4}$ causes the concentration of gaseous MSA in the firn air to be locally elevated, which leads to a net transport of MSA away from the volcanic layer. Why the MSA accumulates above and not below the acidic layer remains unexplained.

The same is observed for $\mathrm{NO}_{3}{ }^{-}$, which is also known to undergo post-depositional redistribution; gas-phase diffusion as $\mathrm{HNO}_{3}$ has been proposed (Röthlisberger and others, 2000a, 2002), analogous to the presumed mechanism for $\mathrm{MSA}^{-}$. $\mathrm{F}^{-}$, which in peaks most likely originates from the same volcanic eruption as adjacent $\mathrm{SO}_{4}{ }^{2-}$ peaks, is found enhanced in the same layers as $\mathrm{NO}_{3}{ }^{-}$, and equivalent mechanisms are probably responsible for the migration of $\mathrm{F}^{-}$.

Post-depositional net loss of $\mathrm{MSA}^{-}$and $\mathrm{NO}_{3}{ }^{-}$have been reported for central East Antarctic sites; but with the above observations it should be expected that even at Berkner a loss of $\mathrm{MSA}^{-}, \mathrm{NO}_{3}{ }^{-}$and $\mathrm{F}^{-}$occurs at volcanic horizons with high acidity in the years after deposition.

In addition to the post-depositional redistribution processes already described, strong reduction of $\mathrm{MSA}^{-}$was also encountered in the core since $A D 1600$, i.e. above $\approx 70 \mathrm{~m}$ depth (see Fig. 8). This probably reflects a net loss of MSA from the chemistry strips during 5 years of storage. They had been cut in 1996 (cross-section: $2.5 \mathrm{~cm} \times 3.0 \mathrm{~cm}$ ) but were not processed further until 2001. Although the strips were sealed into polyethylene sleeves and stored at $-20^{\circ} \mathrm{C}$, this seems to be the most probable explanation. No comparable decrease of $\mathrm{MSA}^{-}$is observed in the $\mathrm{R} 1$ core which was measured soon after retrieval (Fig. 8), although the two records compare well otherwise. Furthermore, the $\mathrm{MSA}^{-}$ record of B25 exhibits a conspicuous correlation to density; the record seems to be stable before AD 1600 (below $70 \mathrm{~m}$ depth), which corresponds to a density $\geq 0.85 \mathrm{~g} \mathrm{~cm}^{-3}$, i.e. well below pore close-off.

The same phenomenon is observed in $\mathrm{B} 25$ for $\mathrm{NO}_{3}{ }^{-}$at the same depth (see Fig. 8). In addition, an unrealistically strong increase of $\mathrm{NO}_{3}{ }^{-}$concentrations was observed in the top $40 \mathrm{~m}$ of B25 as the firn becomes increasingly less dense. It appears that the loss of $\mathrm{NO}_{3}{ }^{-}$during the time of storage may be overridden by contamination during handling or storage. Hence, it is advisable to perform measurements of $\mathrm{MSA}^{-}$and $\mathrm{NO}_{3}{ }^{-}$on firn cores as soon as possible after retrieval of the core and cutting of the aliquots.

\section{CONCLUSIONS}

The method of continuous ice-core melting as a means to provide decontaminated sample to CFA methods has been extended in this application to provide contamination-free sample for discrete IC measurements. It has undisputed advantages in terms of depth resolution and time efficiency over the traditional methods of sample preparation for measurements at risk of contamination. However, it requires good core quality because it is very inflexible (e.g. at nonrectangular core breaks).

The core was datable by identifying volcanic horizons and interpolative annual-layer counting. Only very large volcanic eruptions can be identified, and the dating may become more difficult for deeper layers as well-documented volcanic horizons become scarce. For some species, annuallayer recognition should be possible down to a layer thickness of $\approx 3 \mathrm{~cm}$ (especially sea-salt proxies, conductivity

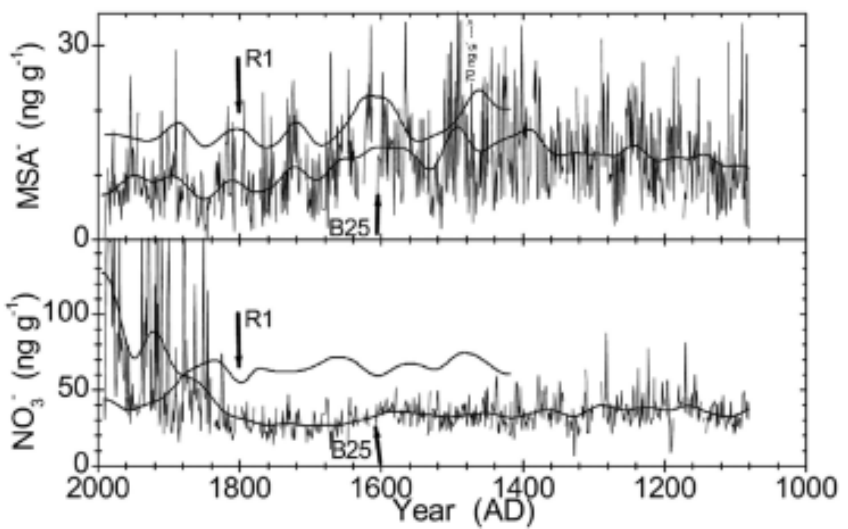

Fig. 8. Loss of MSA presumably during sample storage for B25 (upper panel); loss and contamination of $\mathrm{NO}_{3}{ }^{-}$(lower panel). Annual means (thin lines) and 500 iterations binomially smoothed values (heavy line) for B25; smoothed values are shown for R1. The vertical arrows mark $0.85 \mathrm{~g} \mathrm{~cm}^{-1}$ density for each core. See text for discussion.

and ECM). In the deep core, which is currently being retrieved, this should correspond roughly to the last deglaciation, if it exists in the core and Berkner Island had not been overrun by the Antarctic ice sheet.

The relative seasonal phasings of the microparticle peaks and the $\mathrm{NH}_{4}{ }^{+}$peaks have been found to be more irregular than expected with respect to the sea-salt peak and with respect to each other. Long-term averaging of the seasonality leads to rapid smoothing. For microparticle concentrations a small seasonal enhancement is found 3 months after the seasalt maximum, i.e. microparticles tend to peak in spring. (Note that a depth difference of one-twelfth of the annuallayer thickness is called 1 month here.) For $\mathrm{NH}_{4}{ }^{+}$, seasonal averaging reveals a very slight enhancement during midsummer. The irregular seasonal phasings for microparticles as well as $\mathrm{NH}_{4}{ }^{+}$suggest proximal or multiple sources or significantly less seasonality in transport efficiency for Berkner compared to central East Antarctic sites.

The continuous and high-resolution particle measurements proved helpful for the dating; it was possible to clearly identify a large particle peak dated AD 1600 in other cores (Thompson and others, 1994) and to transcribe the date of this event to the B25 core. Furthermore, the occurrence of high particle peaks together with enhancements of $\mathrm{F}^{-}$may form an indicator for a local volcanic event even in the absence of $\mathrm{nsSO}_{4}{ }^{2-}$; the potential of this indicator should be further investigated. This may show that the volcanic activity of the past has been underestimated so far.

Berkner Island shows a 1000 year record of stable climate; no first-order trends were observed in the species analyzed. The recent increase of accumulation rate and $\delta^{18} \mathrm{O}$ are within the range and rate of change of previous variations. However, the increasing accumulation rate over the last 100 years seems to be the most consistent climatic signal from the Weddell Sea region, as it is also found in studies from the Antarctic Peninsula (Thompson and others, 1994) and also at South Pole (Mosley-Thompson and others, 1995).

Negligible correlation is found between $\delta^{18} \mathrm{O}$, the accumulation rate and $\mathrm{Cl}^{-}$concentrations, and a PCA yields no decomposition of the data. This mirrors the complicated meteorological settings of the Weddell Sea area and may point to the relevance of cyclonic activity. Further investigations 
are required of the relations between temperature, sea-ice extent, storminess, accumulation and marine productivity, as well as their respective proxies in the ice core.

The chemical and isotopic records exhibit an unexpected degree of variability between the two cores. This may be caused by variable regional-scale patterns of atmospheric circulation. The north dome is influenced more directly by the local marine environment; therefore, it is more susceptible to changes of circulation on smaller spatial scales, and the south dome is the more appropriate site to undertake a deep drilling. The best agreement between the two cores is for marine biogenic sulphur species; therefore the Berkner Island deep drilling should provide a good record of biologic productivity in the Weddell Sea region.

Post-depositional redistribution was observed for $\mathrm{MSA}^{-}$, $\mathrm{NO}_{3}{ }^{-}$and $\mathrm{F}^{-}$at volcanic horizons, and a transport mechanism via gas-phase diffusion in firn air is proposed to explain the observations. Post-depositional losses were observed for MSA and $\mathrm{NO}_{3}{ }^{-}$during the 5 years of sample storage; this affected firn and ice with a density $\leq 0.85 \mathrm{~g} \mathrm{~cm}^{-3}$; therefore, shallow cores should be analyzed as soon as possible after core recovery.

\section{ACKNOWLEDGEMENTS}

We thank the field teams from the 1994/95 Antarctic expeditions for the retrieval of the ice cores. B. Stauffer, S. Sommer and M. Bigler (University of Bern) kindly provided the analytical systems for $\mathrm{Ca}^{2+}$ and $\mathrm{NH}_{4}{ }^{+}$; their help is gratefully acknowledged. We thank H.-G. Junghans for his role in developing the melting and autosampler devices. Stable-isotope analysis was financially supported by the Deutsche Forschungsgemeinschaft under Re762/2. Two anonymous reviewers are thanked for their comments on the manuscript.

\section{REFERENCES}

Basile, I., F. E. Grousset, M. Revel, J.R. Petit, P. E. Biscaye and N. I. Barkov. 1997. Patagonian origin of glacial dust deposited in East Antarctica (Vostok and Dome C) during glacial stages 2, 4 and 6. Earth Planet. Sci. Lett., 146(3-4), 573-589.

Fischer, H. and 7 others. 1998. Little Ice Age clearly recorded in northern Greenland ice cores. Geophys. Res. Lett., 25(10), $1749-1752$.

Gerland, S., H. Oerter, J. Kipfstuhl, F. Wilhelms, H. Miller and W. D. Miners. 1999. Density log of a $181 \mathrm{~m}$ long ice core from Berkner Island, Antarctica. Ann. Glaciol., 29, 215-219.

Huke, M. 1998. Die Tritiumzeitreihe von Berkner Island, Antarktis: Natürlicher Hintergrund und Bombenpeak. (M.Sc. thesis, Universität Heidelberg.)

Kreutz, K.J., P.A. Mayewski, L. D. Meeker, M.S. Twickler, S.I Whitlow and I.I. Pittalwala. 1997. Bipolar changes in atmospheric circulation during the Little Ice Age. Science, 277(5330), 1294-1296.

Langway, C. C., Jr, K. Osada, H. B. Clausen, C. U. Hammer and H. Shoji. 1995. A 10-century comparison of prominent bipolar volcanic events in ice cores. J. Geophys. Res., 100(D8), 16,241$16,247$.

Legrand, M., F.M. Ducroz, D. Wagenbach, R. Mulvaney and J. Hall. 1998. Ammonium in coastal Antarctic aerosol and snow: role of the polar ocean and penguin emissions. J. Geophys. Res., 103(D9), 11,043-11,056.

Minikin, A., D. Wagenbach, W. Graf and J. Kipfstuhl. 1994. Spatial and seasonal variations of the snow chemistry at the central Filchner-Ronne Ice Shelf, Antarctica. Ann. Glaciol., 20, 283-290.

Moore, J.C., H. Narita and N. Maeno. 1991. A continuous 770-year record of volcanic activity from East Antarctica. J. Geophys. Res., 96(D9), 17,353-17,359.

Mosley-Thompson, E. 1980. 911 years of microparticle deposition at the South Pole: a climatic interpretation. Ohio State Univ. Inst. Polar Stud. Rep. 73.

Mosley-Thompson, E. and 6 others. 1995. Recent increase in South Pole snow accumulation. Ann. Glaciol., 21, 131-138.

Mulvaney, R. and 8 others. 2002. 1000 year ice-core records from Berkner Island, Antarctica. Ann. Glaciol., 35, 45-51.

Nye, J. F. 1963. Correction factor for accumulation measured by the thickness of the annual layers in an ice sheet. J. Glaciol., 4(36), 785-788.

Pasteur, E.C. and R. Mulvaney. 2000. Migration of methane sulphonate in Antarctic firn and ice. J. Geophys. Res., 105(D9), 11,525-11,534

Rankin, A. M., V. Auld and E.W. Wolff. 2000. Frost flowers as a source of fractionated sea salt aerosol in the polar regions. Geophys. Res. Lett., 27(21), 3469-3472.

Reijmer, C., W. Greuell and J. Oerlemans. 1999. The annual cycle of meteorological variables and the surface energy balance on Berkner Island, Antarctica. Ann. Glaciol., 29, 49-54.

Röthlisberger, R., M.A. Hutterli, S. Sommer, E.W. Wolff and R. Mulvaney. 2000a. Factors controlling nitrate in ice cores: evidence from the Dome C deep ice core. J. Geophys. Res., 105(D16), 20,565-20,572.

Röthlisberger, R. and 6 others. 2000b. Technique for continuous high-resolution analysis of trace substances in firn and ice cores. Environ. Sci. Technol., 34(2), 338-342.

Röthlisberger, R. and 10 others. 2002. Nitrate in Greenland and Antarctic ice cores: a detailed description of post-depositional processes. Ann. Glaciol., 35, 209-216.

Ruth, U., D. Wagenbach, M. Bigler, J. P. Steffensen, R. Röthlisberger and $\mathrm{H}$. Miller. 2002. High-resolution microparticle profiles at NorthGRIP, Greenland: case studies of the calcium-dust relationship. Ann. Glaciol., 35, 237-242.

Ruth, U., D. Wagenbach, J.P. Steffensen and M. Bigler. 2003. Continuous record of microparticle concentration and size distribution in the central Greenland NGRIP ice core during the last glacial period. J. Geophys. Res., 108(D3). (10.1029/ 2002JD002376.)

Sommer, S. and 9 others. 2000a. Glacio-chemical study spanning the past $2 \mathrm{kyr}$ on three ice cores from Dronning Maud Land, Antarctica. 1. Annually resolved accumulation rates. J. Geophys. Res., 105(D24), 29,411-29,421.

Sommer, S., D. Wagenbach, R. Mulvaney and H. Fischer. 2000b. Glacio-chemical study spanning the past $2 \mathrm{kyr}$ on three ice cores from Dronning Maud Land, Antarctica. 2. Seasonally resolved chemical records. J. Geophys. Res., 105(D24), 29,423-29,433.

Thompson, L. G. and 7 others. 1994. Climate since AD 1510 on Dyer Plateau, Antarctic Peninsula: evidence for recent climate change. Ann. Glaciol., 20, 420-426.

Tuncel, G., N. K. Aras and W. H. Zoller. 1989. Temporal variations and sources of elements in the South Pole atmosphere. 1. Nonenriched and moderately enriched elements. J. Geophys. Res., 94(D10), 13,025-13,038.

Wagenbach, D. 1996. Coastal Antarctica: atmospheric chemical composition and atmospheric transport. In Wolff, E.W. and R.C. Bales, eds. Chemical exchange between the atmosphere and polar snow. Berlin, etc., Springer-Verlag, 173-199. (NATO ASI Series I: Global Environmental Change 43.)

Wagenbach, D. and 6 others. 1994. Reconnaissance of chemical and isotopic firn properties on top of Berkner Island, Antarctica. Ann. Glaciol., 20, 307-312.

Wagenbach, D. and 7 others. 1998. Sea-salt aerosol in coastal Antarctic regions. J. Geophys. Res., 103(D9), 10,961-10,974.

Weller, R., F. Traufetter, H. Fischer, H. Oerter, C. Peel and H. Miller. 2004. Post-depositional losses of methane sulfonate, nitrate, and chloride at the EPICA deep-drilling site in Dronning Maud Land, Antarctica. J. Geophys. Res., 109(D7). (10.1029/ 2003JD004189.) 